\title{
THE MULTIANNUAL VARIABILITY IN THE OCCURRENCE OF THE TEMPERATURE INDICES IN THE PYRZYCKO-STARGARDZKA PLAIN MESOREGION
}

\author{
WIELOLETNIA ZMIENNOŚĆ WYSTĘPOWANIA DNI I NOCY \\ CHARAKTERYSTYCZNYCH POD WZGLEDDEM TERMICZNYM \\ W MEZOREGIONIE RÓWNINA PYRZYCKO-STARGARDZKA
}

\author{
Department of Meteorology and Landscape Architecture, West Pomeranian University \\ of Technology, Szczecin, Poland \\ ${ }^{1}$ Institute of Technology and Life Sciences, West Pomeranian Research Centre in Szczecin, Poland
}

\begin{abstract}
Streszczenie. Dni charakterystyczne pod względem termicznym oznaczają dni z temperaturą powietrza (maksymalną lub minimalną) przekraczającą określone wartości progowe. Dni charakteryzujące się szczególnie niską lub wysoką temperaturą powietrza mają znaczenie dla zdrowia i życia człowieka oraz wielu dziedzin gospodarki, np. rolnictwa, energetyki i turystyki. Celem pracy była analiza zmienności i częstości występowania dni charakterystycznych pod względem termicznym w latach 1961-2015 w mezoregionie Równina Pyrzycko-Stargardzka. Wykorzystany w opracowaniu materiał źródłowy obejmował maksymalne i minimalne dobowe wartości temperatury powietrza ze stacji agrometeorologicznej w Lipniku, zlokalizowanej w centralnej części Równiny. W celu określenia dni charakterystycznych pod względem termicznym wykorzystano klasyfikację Kossowskiej-Cezak (2014). Stwierdzono, że znacznie częściej występowały dni charakterystyczne pod względem termicznym dla chłodnej połowy roku $(24,0 \%)$ niż dla ciepłej $(8,9 \%)$. Uzyskane wyniki wskazują na istotny statystycznie ujemny trend liczby dni z przymrozkiem, mroźnych i bardzo mroźnych oraz na dodatni trend liczby dni gorących, upalnych i bardzo upalnych. Największym istotnym statystycznie spadkiem odznaczały się dni mroźne (3,6 na 10 lat), a największym wzrostem - dni gorące (2,3 na 10 lat). Wykazano, że w analizowanym wieloleciu najwięcej było dni z przymrozkiem $(62,4)$ i dni gorących $(26,7)$. Stwierdzono również, że przeciętnie w roku notuje się 15,7 nocy mieszczących się $w$ wybranych wartościach progowych, $z$ tym że większość stanowią noce ciepłe. Wykazano także istotny statystycznie wzrost liczby takich nocy o 2,5 na 10 lat.
\end{abstract}

Key words: maximum air temperature, minimum air temperature, north-west Poland, temperature indices.

Słowa kluczowe: wskaźniki temperatury, północno-zachodnia Polska, temperatura maksymalna, temperatura minimalna.

\section{INTRODUCTION}

Air temperature is a basic characteristic used in determination of climatic conditions of a given area (Trepińska 2005; Kossowska-Cezak 2014). A distinctive feature of the climate of western Pomerania is a great variability of thermal conditions in a year (Koźmiński and

Corresponding author - Adres do korespondencji: Agnieszka Mąkosza, Department of Meteorology and Landscape Architecture, West Pomeranian University of Technology, Szczecin, Papieża Pawła VI 3A, 71-459 Szczecin, Poland, e-mail agnieszka.makosza@zut.edu.pl 
Michalska 2000). Mean 24-hour air temperature in this area is $8.2^{\circ} \mathrm{C}$ on average and a statistically significant increase has been observed since the $1980 \mathrm{~s}$. In the period 1961-2000, the highest recorded 24-hour air temperature was $38.0^{\circ} \mathrm{C}$ and the lowest $-28.6^{\circ} \mathrm{C}$ (Michalska 2011; Koźmiński et al. 2012). In the analysis of thermal conditions, of particular importance are the extreme values which significantly affect health and well-being as well as agriculture, energy industryand tourism (Kossowska-Cezak and Twardosz 2013). According to Twardosz and Kossowska-Cezak (2015), the occurrence of extremely negative thermal conditions is an inherent characteristic of a climate determined by an intensely varied atmospheric circulation.

The analyses of extreme air temperatures by Bielec-Bąkowska and Piotrowicz (2013) showed that in the Szczecin Lowland, there is a statistically significant downward trend with a minimum temperature ( $\leq 10$ percentile) and an upward trend with maximum temperature ( $\geq 90$ percentile). Additionally, studies on extreme thermal conditions in Poland and Europe indicate a significant trend of climate warming which leads to, among others, a rapid increase in the number of hot and very hot days, warm nights and a decrease in the number of days termed as cold or frosty (Brázdil et al. 1995; Yan et al. 2002; Wibig and Głowicki 2002; Koźmiński and Michalska 2010, 2011). The occurrence of extremely high or low air temperature in a 24-hour period which exceeds specific threshold is referred to as a day with extreme temperature (hot, very hot, extremely hot, with frost, cold, very cold, extremely cold), and a night with extreme temperature (warm, very warm, tropical) (Błażejczyk and Kuchcik 2011; Koźmiński and Michalska 2011; Kossowska-Cezak 2014; Więcław 2015). Numerous studies concern the analysis of variability and frequency of days with particular temperature indices in a given region (Piotrowicz 2007a; Koźmiński and Michalska 2010; KossowskaCezak and Skrzypczuk 2011, Więcław 2015), as well as in the whole area of Poland (Cebulak and Limanówka 2007; Koźmiński and Michalska 2011). The aforementioned studies point to considerable regional variations in the occurrence of such days.

Therefore, the aim of this paper is to determine variability and frequency of days and nights with particular temperature indices in the period 1961-2015 in the Pyrzycko-Stargardzka Plain mesoregion.

\section{MATERIAL AND METHODS}

This study based on daily maximum and minimum values of air temperature recorded in the period 1961-2015. The data used for the analysis was obtained from the agrometeorological station in Lipnik (near Stargard). The station is located in the central part of the Pyrzycko-Stargardzka Plain $\left(14^{\circ} 58 \mathrm{E}, 53^{\circ} 21 \mathrm{~N}\right), 1.8 \mathrm{~km}$ to the north-east of Miedwie Lake, $30 \mathrm{~m}$ above sea level.

The occurrence of days with extreme temperature values are determined on the basis of air temperature exceeding the given thresholds. In terms of terminology, days with particular temperature indices often referres to similar terms, despite different identification criteria. The 
classification of temperature indices studied by Kossowska-Cezak (2014) was used in the present paper:

- frost days $\left(t_{\min }<0.0^{\circ} \mathrm{C}, t_{\max } \geq 0.0^{\circ} \mathrm{C}\right)$,

- cold days $\left(0.0^{\circ} \mathrm{C}>t_{\max } \geq-10.0^{\circ} \mathrm{C}\right)$,

- very cold days $\left(-10.0^{\circ} \mathrm{C}>t_{\max } \geq-20.0^{\circ} \mathrm{C}\right)$,

- extremely cold days $\left(t_{\max }<-20^{\circ} \mathrm{C}\right)$,

- hot days $\left(25.0^{\circ} \mathrm{C}<\mathrm{t}_{\max } \leq 30^{\circ} \mathrm{C}\right)$,

- very hot days $\left(30.0^{\circ} \mathrm{C}<t_{\max } \leq 35.0^{\circ} \mathrm{C}\right)$,

- extremely hot days $\left(t_{\max }>35.0^{\circ} \mathrm{C}\right)$,

and

- warm nights $\left(15.0^{\circ} \mathrm{C}<t_{\min } \leq 18.0^{\circ} \mathrm{C}\right)$,

- very warm nights $\left(18.0^{\circ} \mathrm{C}<t_{\min } \leq 20.0^{\circ} \mathrm{C}\right)$,

- tropical nights $\left(t_{\min }>20.0^{\circ} \mathrm{C}\right)$.

With the use of linear regression analysis, it was possible to determine the direction and rate of a long-term trend in variation of the number of days as well as nights showing particular values of temperature indices in the cold and warm periods of a year. The same calculations were made as for individual months in which specific temperature indices were observed. Statistical significance of the regression function at the 0.05 and 0.01 levels was determined with the use of t-Student test.

\section{RESULTS AND DISCUSSION}

In the analysed period of 1961-2015 in the Pyrzycko-Stargardzka Plain Mesoregion a statistically significant positive trend in the absolute and mean values of maximum as well as minimum temperature was observed. However, as it is presented in Table 1, the observed increase also applies to the absolute minimum temperature, yet it is not statistically significant. The increase in absolute maximum and minimum temperature was 0.7 and $0.5^{\circ} \mathrm{C}$ per 10 years, respectively. Additionally, greater annual fluctuations i.e., from $-7.3^{\circ} \mathrm{C}$ in 1990 to even $-28.6^{\circ} \mathrm{C}$ in 1987 , were found for absolute values of minimum temperature. In turn, the highest recorded values of maximum temperature ranged from $29.2^{\circ} \mathrm{C}$ in 1962 and 1965 to $38.0^{\circ} \mathrm{C}$ in 1998. Slightly lower maximum values were recorded in 1992, 1994, 2006 and 2015 - over $37^{\circ} \mathrm{C}$. In the Pyrzycko-Stargardzka Plain Mesoregion the average annual maximum temperature was $12.9^{\circ} \mathrm{C}$ and ranged from $9.8^{\circ} \mathrm{C}$ to $15.6^{\circ} \mathrm{C}$, and the average minimum temperature was $4.6^{\circ} \mathrm{C}$ and ranged from $2.4^{\circ} \mathrm{C}$ to $6.1^{\circ} \mathrm{C}$. The difference between 24-hour mean maximum and minimum temperature was $8.3^{\circ} \mathrm{C}$, with the smallest difference recorded in $1977\left(7.0^{\circ} \mathrm{C}\right)$ and the highest in $2006\left(10.4^{\circ} \mathrm{C}\right)$. According to Bielec-Bąkowska and Piotrowicz (2013), in Poland in the period 1951-2006, the highest mean maximum temperatures were recorded at stations located in the west (for example in Wroctaw $13.4^{\circ} \mathrm{C}$ ), and the lowest mean minimum temperatures were recorded in the east (for example in Suwałki $2.3^{\circ} \mathrm{C}$ ), excluding mountain areas. 
Table 1. Trend equations of extreme temperatures. Years 1961-2015

Tabela 1. Równania trendu wartości temperatury ekstremalnej. Lata 1961-2015

\begin{tabular}{|c|c|c|c|c|c|c|}
\hline \multirow{2}{*}{$\begin{array}{c}\text { Extreme temperature } \\
\text { Temperatury } \\
\text { ekstremalne }\end{array}$} & \multirow{2}{*}{$\begin{array}{l}\text { Trend equation } \\
\text { Równanie trendu }\end{array}$} & \multirow[b]{2}{*}{$\mathrm{R}^{2}$} & \multirow{2}{*}{$\begin{array}{c}\text { Change } \\
\text { in the number } \\
\text { of days } \\
\text { per } 10 \text { years } \\
\text { Wzrost/ } \\
\text { spadek liczby } \\
\text { dni } \\
\text { na10 lat }\end{array}$} & \multicolumn{3}{|c|}{$\begin{array}{l}\text { Value and date } \\
\text { Wartość i data }\end{array}$} \\
\hline & & & & $\begin{array}{l}\text { average } \\
\text { średnia }\end{array}$ & $\begin{array}{l}\text { lowest } \\
\text { najniższa }\end{array}$ & $\begin{array}{l}\text { highest } \\
\text { najwyższa }\end{array}$ \\
\hline $\begin{array}{l}\text { Absolute maximum } \\
\text { Absolutna } \\
\text { maksymalna }\end{array}$ & $y=0.07 x+30.989$ & $0.263^{\star *}$ & 0.7 & $33.1^{\circ} \mathrm{C}$ & $\begin{array}{c}29.2^{\circ} \mathrm{C} \\
15.06 .1962 \\
14.07 .1965\end{array}$ & $\begin{array}{c}38^{\circ} \mathrm{C} \\
21.07 .1998\end{array}$ \\
\hline $\begin{array}{l}\text { Average maximum } \\
\text { Średnia maksymalna }\end{array}$ & $y=0.05 x+11.616$ & $0.306^{\star \star}$ & 0.4 & $12.9^{\circ} \mathrm{C}$ & $\begin{array}{l}9.8^{\circ} \mathrm{C} \\
1996\end{array}$ & $\begin{array}{l}15.6^{\circ} \mathrm{C} \\
2006\end{array}$ \\
\hline $\begin{array}{l}\text { Absolute minimum } \\
\text { Absolutna minimalna }\end{array}$ & $y=0.05 x-17.861$ & 0.025 & 0.5 & $-16.4^{\circ} \mathrm{C}$ & $\begin{array}{c}-28.6^{\circ} \mathrm{C} \\
14.01 .1987\end{array}$ & $\begin{array}{l}-7.3^{\circ} \mathrm{C} \\
9.04 .1990\end{array}$ \\
\hline $\begin{array}{l}\text { Average minimum } \\
\text { Średnia minimalna }\end{array}$ & $y=0.03 x+3.746$ & $0.261^{\star *}$ & 0.3 & $4.6^{\circ} \mathrm{C}$ & $\begin{array}{r}2.4^{\circ} \mathrm{C} \\
1996\end{array}$ & $\begin{array}{l}6.1^{\circ} \mathrm{C} \\
2014\end{array}$ \\
\hline
\end{tabular}

*Statistically significant - Poziom istotności $-\alpha 0.05 . \quad$ ** Statistically significant - Poziom istotności $-\alpha \quad 0.01$.

Low temperatures have a negative effect on the human body due to cold stress and may lead to frostbite and hypothermia (Błażejczyk and Kunert, 2011). Such temperatures may also cause freezing of winter cereals, flowers and fruit primordia which results in significant decrease in yield (Trepińska and Kopycki 2009). It was found that in the analysed period 1961-2015, there was a decrease in the total number of days with particular temperature indices (frost days, cold days and very cold days) from 100 days recorded in the 1960s and 1970s to 74-90 days in following years. The lowest occurrence of particular temperature indices was recorded in 1994 (50 days) and the highest in 1970 (131 days) - Fig.1.

Single linear regression analysis confirmed the negative trend of almost 6 days per 10 years (Table 2). The decrease in the number of frost days, cold and very cold days was also recorded in other regions of Poland and documented by numerous studies by Wibig and Głowicki (2002), Kossowska-Cezak (2014), Matuszko and Piotrowicz (2012). In the analysed period of 55 years in the Pyrzycko-Stargardzka Plan, frost days were predominant and their number in particular years ranged from 38 to 101 days with marked, yet statistically insignificant, downward trend of 2.0 days per 10 years. On average, 25 cold days were recorded each year, yet the number of such days was almost two times higher till 1987 than that recorded in subsequent years. The cold days were characterised by the highest statistically significant downward trend of 3.5 days per 10 years. The highest number of cold days (68) was found in 1963, and the lowest in 1974 - 3 days. Days with maximum temperature from $-10.0^{\circ} \mathrm{C}$ to $-20.0^{\circ} \mathrm{C}$ labelled as very cold occurred in $25 \%$ of the analysed years - from 1 to 6 days. It should, however, be noted that very cold days were less frequent and recorded only on individual days. In the analysed period, there were no extremely cold days with maximum temperature below $-20^{\circ} \mathrm{C}$. 

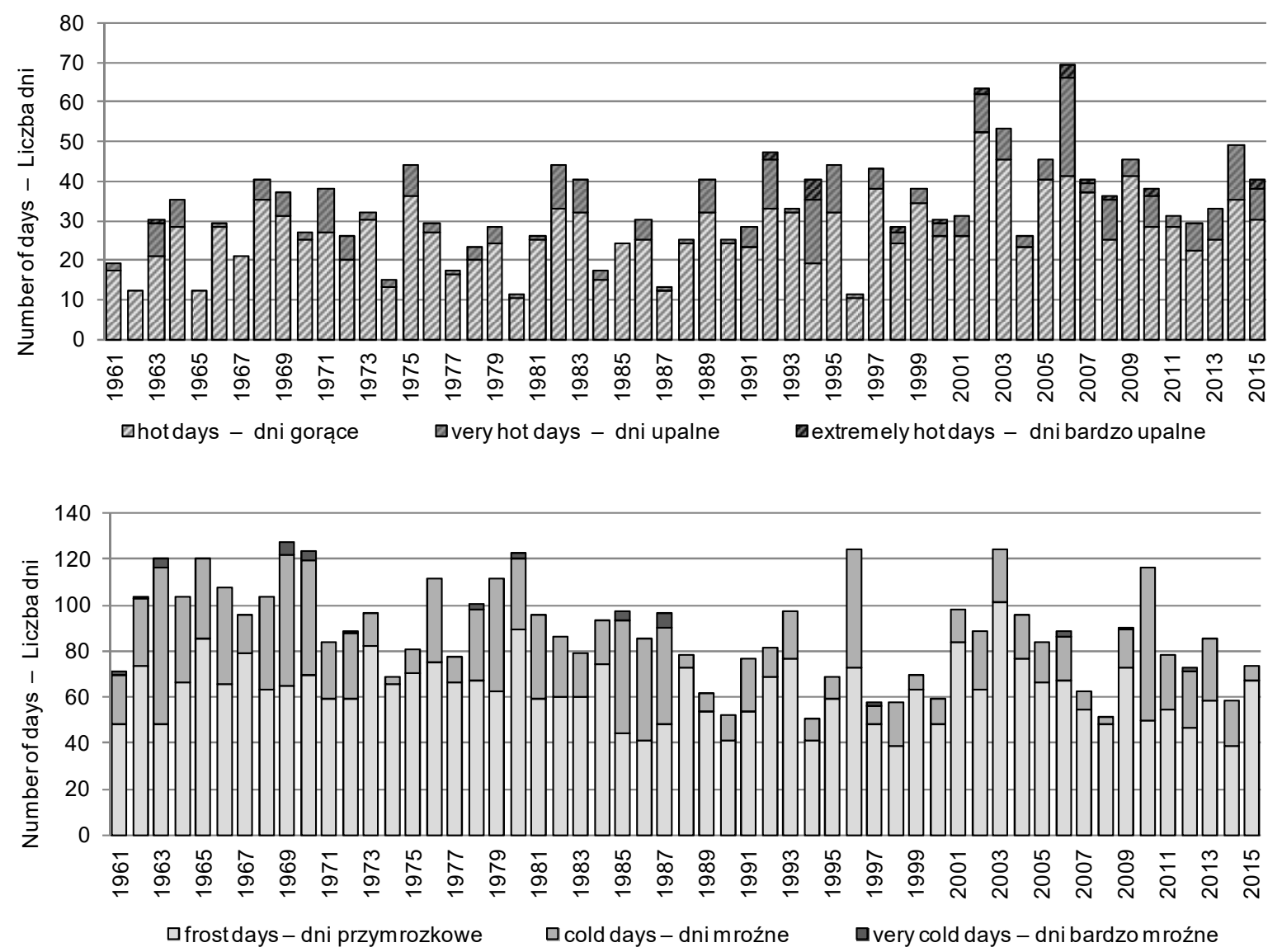

Fig.1. The annual number of hot, very hot, extremely hot, frost, cold and very cold days in the Pyrzycko-Stargardzka Plain. Years 1961-2015

Ryc. 1. Roczna liczba dni gorących, upalnych, bardzo upalnych, z przymrozkiem, mroźnych i bardzo mroźnych na Równinie Pyrzycko-Stargardzkiej. Lata 1961-2015

Table 2. Trend equations of the selected temperature indices for a daytime in the Pyrzycko-Stargardzka Plain. Years 1961-2015

Tabela 2. Równania trendu wybranych wskaźników temperatury określonych dla dni na Równinie Pyrzycko-Stargardzkiej. Lata 1961-2015

\begin{tabular}{lllc}
\hline \multicolumn{1}{c}{$\begin{array}{c}\text { Thermal classification } \\
\text { Klasyfikacja termiczna }\end{array}$} & $\begin{array}{c}\text { Trend equation } \\
\text { Równanie trendu }\end{array}$ & $\mathrm{R}^{2}$ & $\begin{array}{c}\text { Change in the } \\
\text { number of days } \\
\text { per } 10 \text { years } \\
\text { Wzrost/ spadek } \\
\text { liczby dni na10 lat }\end{array}$ \\
\hline $\begin{array}{l}\text { Total number of days (frost days, cold, very cold) } \\
\text { Suma dni (z przymrozkiem, mroźnych, bardzo mroźnych) }\end{array}$ & $\mathrm{y}=-0.59 \mathrm{x}+104.615$ & $0.167^{* *}$ & -5.9 \\
\hline Frost days - Dni z przymrozkiem & $\mathrm{y}=-0.20 \mathrm{x}+67.913$ & 0.048 & -2.0 \\
\hline Cold days - Dni mroźne & $\mathrm{y}=-0.36 \mathrm{x}+35.274$ & $0.117^{*}$ & -3.6 \\
\hline Very cold days - Dni bardzo mroźne & $\mathrm{y}=-0.03 \mathrm{x}+1.428$ & 0.069 & -0.3 \\
\hline Total number of days (hot, very hot days, extremely hot) & $\mathrm{y}=0.35 \mathrm{x}+22.420$ & $0.211^{* *}$ & 3.5 \\
\hline Suma dni (gorących, upalnych, bardzo upalnych) & $\mathrm{y}=0.23 \mathrm{x}+20.208$ & $0.170^{* *}$ & 2.3 \\
\hline Hot days - Dni gorące & $\mathrm{y}=0.11 \mathrm{x}+2.333$ & $0.126^{* *}$ & 1.1 \\
\hline Very hot days - Dni upalne & $\mathrm{y}=0.02 \mathrm{x}+0.121$ & $0.093^{*}$ & 0.2 \\
\hline Extremely hot days - Dni bardzo upalne & & & \\
\hline
\end{tabular}

*Statistically significant - Poziom istotności - a 0.05. ** Statistically significant - Poziom istotności - a 0.01 . 
Extreme air temperatures, both high and low, negatively affect the human body (Błażejczyk and Kuchcik 2011; Matuszko and Piotrowicz 2012; Nidzgorska-Lencewicz and Mąkosza 2013; Czarnecka and Nidzgorska-Lencewicz 2015). High temperatures cause heat stress in plants and animals and, due to excessive evapotranspiration, contribute to negative water balance. High air temperatures, particularly those persisting for a long period of time, disrupt road and rail transport, cause reduction in the capacity of transmission lines and increased energy consumption due to, for example, the use of air-conditioning (Starkel and Kundzewicz 2008; Ziemiański and Ośródka 2012; Krzyżewska 2015). On the grounds of linear regression analysis, it was found that in the analysed period 1961-2015 there was a statistically significant increase in the total number of days characteristic for the warm period of a year by 3.5 days per 10 years (hot, very hot and extremely hot days). The increase has been particularly pronounced since 2002 (Table 2). A positive trend in the number of hot, very hot and extremely hot days observed in other regions of Poland was studied by numerous authors - Koźmiński and Michalska (2010), Matuszko and Piotrowicz (2012), Kossowska-Cezak (2014).

The lowest number of hot, very hot and extremely hot days in the Pyrzycko-Stargardzka Plain was recorded in the 1960s and 1970s (26 days on average). In turn, a record high number i.e. 69, was observed in 2006, 31 out of which occurred only in July (Fig. 1). According to Koźmiński and Michalska (2000), the number of hot and very hot days in July in the Szczecin Lowland in the period 1961-1994 amounted to 25 and 14 days maximum, respectively. In the analysed period, the highest upward trend -2.3 days per 10 years, was found for hot days, and their number ranged from 10 in 1980 and 1996 to 52 in 2002. A slightly lower increase - by 0.8 day per 10 years was determined for very hot days with their highest number (25) recorded in 2006. The occurrence of temperature indices labelled as extremely hot has been identified since 1992. The highest number of extremely hot days, i.e. 5, was recorded in 1994. The analysis of occurrence of extremely hot days by Bielec-Bąkowska and Piotrowicz (2013) shows that 1994 was prominent in terms of occurrence of such temperature indices also in other regions of Poland, particularly from June 26 to August 2. In the Pyrzycko-Stargardzka Plain, the previous years under analysis were marked by only one occurrence of an extremely hot day - recorded on August, 4 1963, with the maximum temperature $35.8^{\circ} \mathrm{C}$ and the minimum temperature $19.9^{\circ} \mathrm{C}$. Consequently, the respective night can be classified as very warm. For the same 24 hour period, Piotrowicz (2007b) identified the occurrence of very warm night in Kraków due to tropical air masses advection.

Usually the night following the day with high maximum temperature is marked with a relatively high minimum temperature which prevents regeneration after a hot day and has a negative effect on the human body (Więcław 2015). In Poland, the occurrence of warm, hot and tropical nights is most often caused by advection of tropical or continental polar air masses (Matuszko and Piotrowicz 2012; Bielec-Bąkowską and Piotrowicz 2013). In the analysed period (1961-2015) the increase in the number of nights with particular temperature indices values in terms of high minimum temperatures was recorded particularly at the turn of the 21st century (Fig. 2). Similar findings were reported by Piotrowicz (2007b), Matuszko and Piotrowicz (2012), Bielec-Bąkowska and Piotrowicz (2013), Kossowska-Cezak (2014) or Więclaw (2015). In the last 15 years of the analysed period (2000-2015) in the Pyrzycko-Stargardzka Plain, approximately 16 nights with extreme temperature indices were recorded,- the highest number occured in 2006 (33 nights). 
The analysis shows that the number of nights, as well as hot, very hot and extremely hot days, is marked by highly statistically significant positive trend with an increase of 2.5 nights per 10 years (Table 3 ). Each year of the analysed period, warm nights were predominant with the frequency of approximately 14 per year, yet in the last 10 years of the analysed period the number of warm nights increased to approximately 19. Very warm nights were recorded significantly less frequently, on average 2 per year. However, in the last 10 years of the analysed period (2005-2015), very warm nights were recorded each year, unlike in the previous years. Tropical nights with minimum temperature over $20^{\circ} \mathrm{C}$ were recorded with similar frequency as extremely hot days, particularly since 1992 - the highest number (3) was recorded in 2010. In the early years of the analysed period, tropical nights were a very rare event (occurred in 1969 and 1984). Table 3 shows that the analysed period of 55 years is marked with the highest increase in the number of warm nights (2.0 days per 10 years), and a slight increase of very warm ( 0.3 day per 10 years) and tropical nights ( 0.1 day per 10 years).

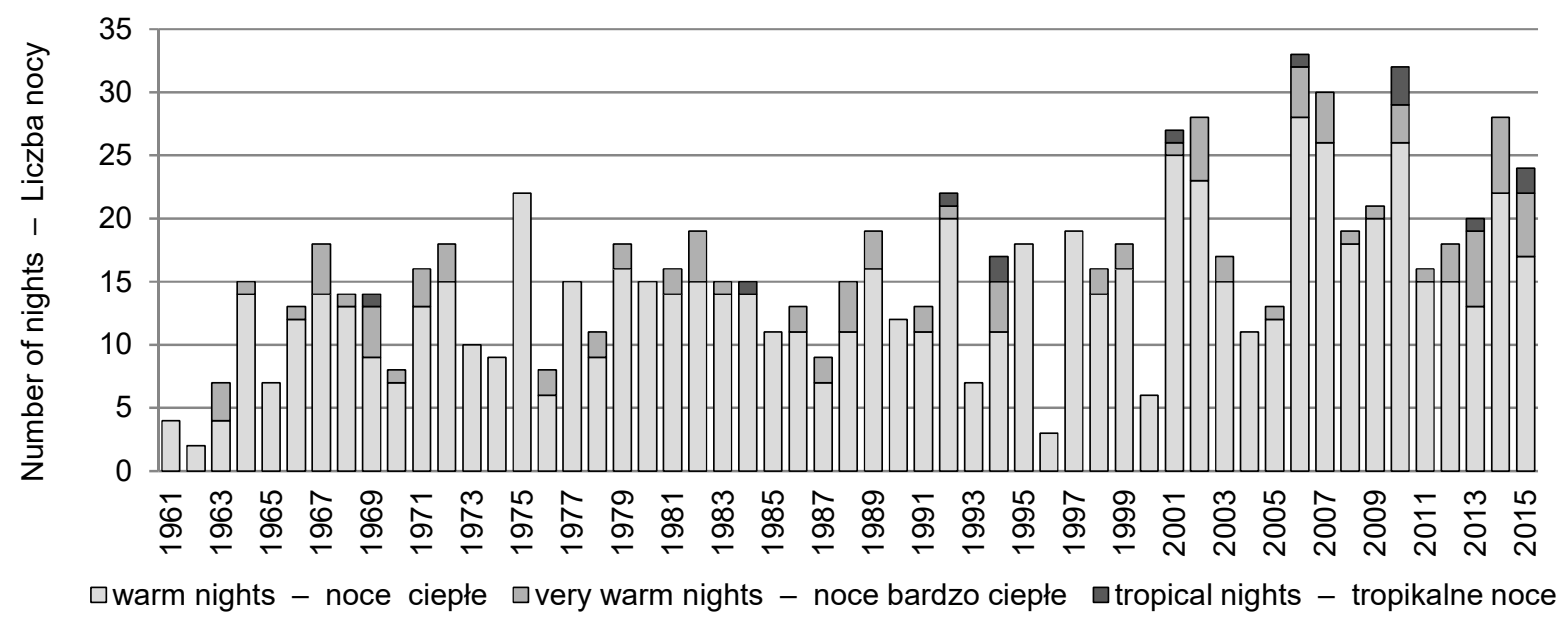

Fig. 2. The annual number of warm, very warm and tropical nights in the Pyrzycko-Stargardzka Plain. Years 1961-2015

Ryc. 2. Roczna liczba nocy ciepłych i bardzo ciepłych oraz tropikalnych nocy na Równinie Pyrzycko-Stargardzkiej. Lata 1961-2015

Table 3. Trend equations of the selected temperature indices for a nighttime in the Pyrzycko-Stargardzka Plain. Years 1961-2015

Tabela 3. Równania trendu wybranych wskaźników temperatury określonych dla nocy na Równinie Pyrzycko-Stargardzkiej. Lata 1961-2015

\begin{tabular}{lccc}
\hline \multicolumn{1}{c}{$\begin{array}{c}\text { Thermal classification } \\
\text { Klasyfikacja termiczna }\end{array}$} & $\begin{array}{c}\text { Trend equation } \\
\text { Równanie trendu }\end{array}$ & $\mathrm{R}^{2}$ & $\begin{array}{c}\text { Change the number of days } \\
\text { per } 10 \text { years }\end{array}$ \\
\hline Total of nights - Suma nocy & $\mathrm{y}=0.25 \mathrm{x}+8.832$ & $0.316^{* *}$ & 2.5 \\
\hline Warm nights - Noce ciepłe & $\mathrm{y}=0.20 \mathrm{x}+8.088$ & $0.288^{* *}$ & 2.0 \\
\hline Very warm nights - Noce bardzo ciepłe & $\mathrm{y}=0.03 \mathrm{x}+0.848$ & $0.099^{*}$ & 0.3 \\
\hline Tropical nights -Tropikalne noce & $\mathrm{y}=0.01 \mathrm{x}-0.105$ & $0.103^{*}$ & 0.1 \\
\hline * Statistically significant - Poziom istotności - $\alpha 0.05 . \quad * *$ Statistically significant - Poziom istotności $-\alpha 0.01$.
\end{tabular}


The frequency of days with recorded particular values of temperature indices as per individual months of the analysed period (1961-2015) is presented in Fig. 3. It was found that frost days, cold and very cold days were recorded with higher frequency (24\%) than hot, very hot and extremely hot days $-8.9 \%$. The earliest date of frost days occurrence was September 18, and the latest June 1. Cold days were recorded predominantly in the winter months (December-February), yet there were instances of cold days recorded as early as November 1, to as late as March 22. Days with even lower maximum temperatures - very cold days, were recorded only in winter from December 17 to February 11. Hot days were recorded from as early as April 13 to November 4. Very hot days were recorded from April 23 to September 1, with the highest frequency in July (2.6 days on average). Occurrence of extremely hot days is characteristic only for the summer months (June-August), and predominantly recorded in July and August.

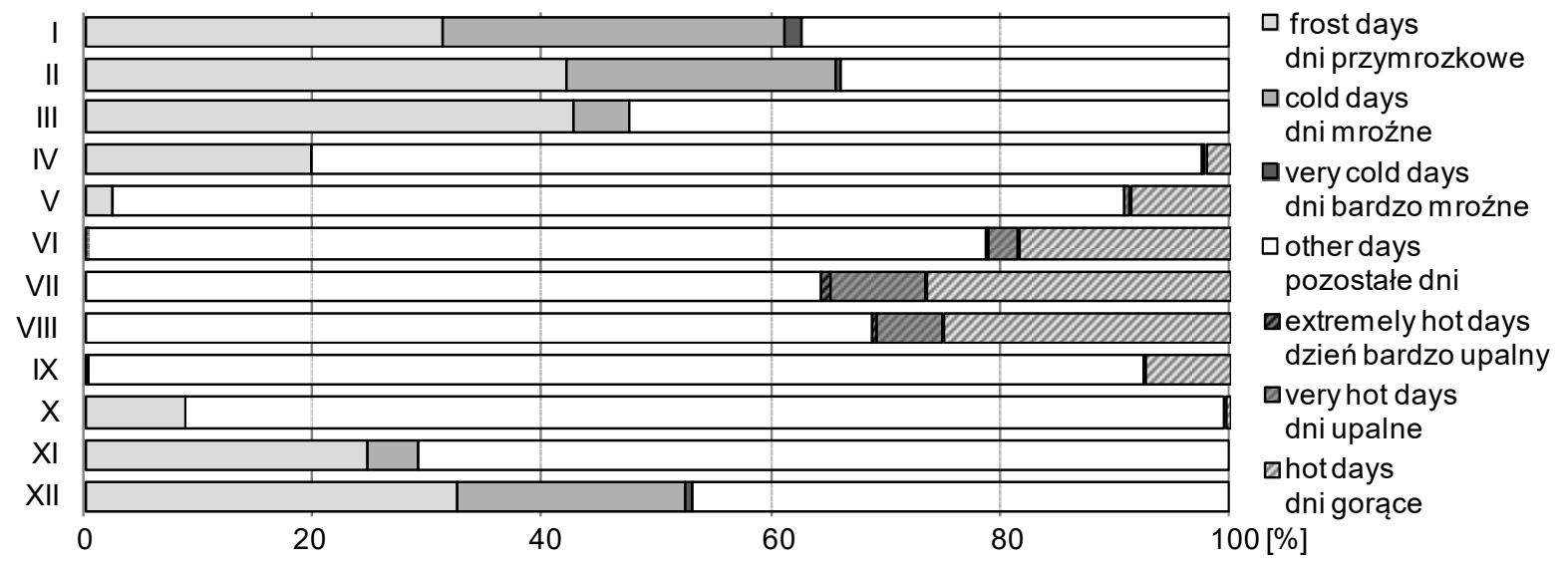

Fig. 3. Frequency of occurrence of the number of days with particular temperature indices in the following months in the Pyrzycko-Stargardzka Plain. Years 1961-2015

Ryc. 3. Częstość występowania dni charakterystycznych pod względem termicznym w kolejnych miesiącach na Równinie Pyrzycko-Stargardzkiej. Lata 1961-2015

In the analysed period 1961-2015 out of all nights with particular temperature indices, warm nights were prevalent and recorded from April 23 to November 9 (Fig. 4). On average, in July and August, 5 such nights were recorded and their maximum number in these two months was 14 in 2006 and 16 in 2010. Very warm nights were recorded only from June 1 to August 24, and tropical nights occurred occasionally - only from July 5 to August 16 . The highest frequency of very warm nights was found in the last decade of July and the first decade of August. Comparable distribution in late July and early August was demonstrated by Więcław (2015) for Chojnice and Poznań. The study by Piotrowicz (2007b) showed that the highest frequency of the tropical nights in Kraków was recorded in July.

With the use of single linear regression, a decrease in the total number of temperature indices was identified in months in which such occurrence was recorded, except for October. However, highly statistically significant negative trend ( 1.9 days per 10 years) in the number of days with particular temperature indices (frost days, cold and very cold days) was 
determined only in December. It was demonstrated that the increase in the total number of hot, very hot and extremely hot days in months in which such days were recorded was statistically significant only in May ( 0.5 day per 10 years) and highly statistically significant in July ( 1.6 day per 10 years) and August ( 1.3 day per 10 years). The analysis of variability of the total number of nights with particular temperature indices demonstrates an upward trend in each month in which such nights occur, with relation to all individual types (classification criteria). However, a statistically significant trend was identified only in August (1.0 day per 10 days) and a highly statistically significant trend was found in July (1.2 day per 10 years) (Table 4).

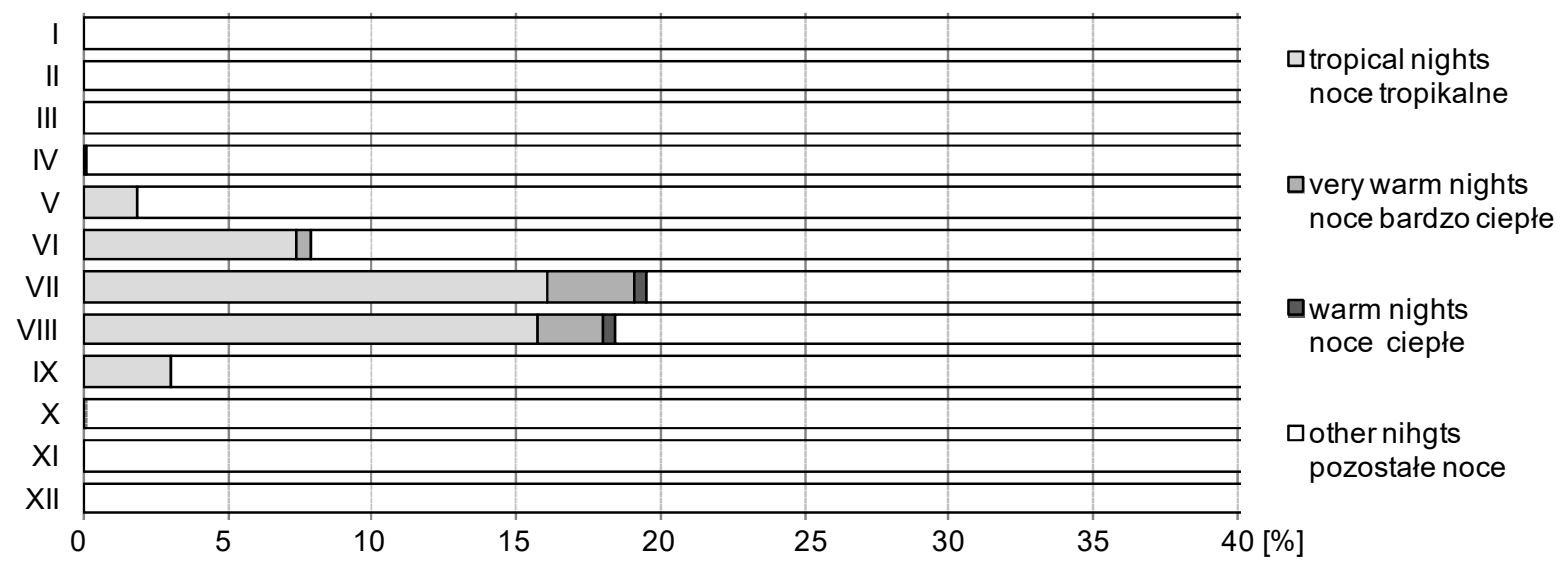

Fig. 4. Frequency of occurrence of the number of nights with particular temperature indices in the following months in the Pyrzycko-Stargardzka Plain. Years 1961-2015

Rys. 4. Częstość występowania nocy charakterystycznych termicznie w kolejnych miesiącach na Równinie Pyrzycko-Stargardzkiej. Llata 1961-2015

Table 4. Trend equations of the number of days with particular temperature indices and nights in selected months in the Pyrzycko-Stargardzka Plain. Years 1961-2015

Tabela 4. Równania trendu liczby dni i nocy charakterystycznych pod względem termicznym w wybranych miesiącach na Równinie Pyrzycko-Stargardzkiej. Lata 1961-2015

\begin{tabular}{|c|c|c|c|c|}
\hline $\begin{array}{l}\text { Thermal classification } \\
\text { Klasyfikacja termiczna }\end{array}$ & $\begin{array}{l}\text { Month } \\
\text { Miesiąc }\end{array}$ & $\begin{array}{l}\text { Trend equation } \\
\text { Równanie trendu }\end{array}$ & $\mathrm{R}^{2}$ & $\begin{array}{c}\text { Change } \\
\text { in the number } \\
\text { of days } \\
\text { per } 10 \text { years } \\
\text { Wzrost/ spadek } \\
\text { liczby dni } \\
\text { na10 lat }\end{array}$ \\
\hline $\begin{array}{l}\text { Total number of frost, cold and very cold days } \\
\text { Suma dni (z przymrozkiem, mroźne, bardzo } \\
\text { mroźne) }\end{array}$ & XII & $y=-0.19 x+21.800$ & $0.164^{\star *}$ & -1.9 \\
\hline \multirow{3}{*}{$\begin{array}{l}\text { Total number of hot, very hot and extremely } \\
\text { hot days } \\
\text { Suma dni (gorące, upalne, bardzo upalne) }\end{array}$} & $\mathrm{V}$ & $y=0.05 x+1.297$ & $0.087^{*}$ & 0.5 \\
\hline & VII & $y=0.16 x+6.585$ & $0.134^{* *}$ & 1.6 \\
\hline & VIII & $y=0.13 x+5.943$ & $0.135^{\star *}$ & 1.3 \\
\hline $\begin{array}{l}\text { Total number of nights (warm, very warm, } \\
\text { tropical) } \\
\text { Suma nocy (ciepłe, bardzo ciepłe, tropikalne) }\end{array}$ & VII & $y=0.12 x+2.567$ & $0.248^{* *}$ & 1.2 \\
\hline
\end{tabular}

\footnotetext{
* Statistically significant - Poziom istotności $-\alpha 0.05 . \quad$ ** Statistically significant - Poziom istotności $-\alpha \quad 0.01$.
} 


\section{CONCLUSION}

It was found that in the analysed period 1961-2015 in the Pyrzycko-Stargardzka Plain there was an increase in the extreme temperatures which was statistically significant only for absolute and mean maximum temperature and mean minimum temperature. The frequency of frost, cold and very cold days characteristic for the cold half of a year, which were observed from late September to early June, was considerably higher (24.0\%) than that of hot, very hot and extremely hot days which occurred in the warm half of a year $(8.9 \%)$ - such days were recorded from April to the first days of October. In the analysed period of 55 years, there was a decrease in the total number of days characteristic for the cold half of a year by 5.9 days per 10 years. On the other hand, an increase in the number of days characteristic was observed for the warm half of a year by 3.5 days per 10 years. Out of all temperature indices, the highest decrease was found for cold days -3.6 days per 10 years, and the highest increase for hot days -2.3 days per 10 years.

Additionally, the analysis shows the negative trend for frost days (2.0 days per 10 years) and very cold days ( 0.3 day per 10 years), and a positive trend for very hot days ( 1.1 day per 10 years) and extremely hot days ( 0.2 day per 10 years). Deterioration of unfavourable thermal conditions resulting from a positive trend of the total number of hot, very hot and extremely hot days was presented particularly in May, July and August. The greatest decrease in the total number of frost, cold and very cold days, i.e. 1.9 day per 10 years, was founded for December. Furthermore, a positive statistically significant trend in the number of nights with particular temperature indices was identified.

The highest increase was found for warm nights (2 nights per 10 years), and significantly lower for very warm nights ( 0.3 night per 10 years) and tropical nights $(0.1$ night per 10 years). Nights with particular thermal indices values were recorded from the third decade of April to the end of the first decade of October, yet very warm nights were observed only from early June to the beginning of the third decade of August, and tropical nights only from the middle of the first decade of July to the middle of the second decade of August. On average, the highest number of days with particular temperature indices characteristic for the cold period of a year was determined for January, and the highest number of days and nights with particular temperature indices characteristic for the warm period of a year - in July. Moreover, in the aforementioned months, the values of air temperature are most extreme.

\section{REFERENCES}

Bielec-Bąkowska Z., Piotrowicz K. 2013. Temperatury ekstremalne w Polsce w latach 1951-2006 [Extreme temperatures in Poland 1951-2006]. Pr. Geogr. IGiGP UJ 132, 59-68. [in Polish]

Błażejczyk K., Kunert A. 2011. Bioklimatyczne uwarunkowania rekreacji i turystyki w Polsce [Bioclimatic principles of recreation and tourism in Poland]. Pr. Geogr. IGiPZ PAN Warsz., Monografie 13. [in Polish]

Brázdil R., Budikova M., Auer I., Böhm R., Cegner T., Fasko P., Lapin M., Gajic-Capka M., Zaninovic K., Koleva E., Niedźwiedź T., Ustrnul Z., Szalai S., Weber R.O. 1995. Trends of maximum and minimum daily temperatures in central and southeastern Europe. Int. J. Clim. 16, 765-782.

Cebulak E., Limanówka D. 2007. Dni z ekstremalnymi temperaturami powietrza w Polsce, w: Wahania klimatu w różnych skalach przestrzennych i czasowych. Red. K. Piotrowicz, R. Twardosz. Kraków, IGiPZ UJ, 185-194. [in Polish] 
Czarnecka M., Nidzgorska-Lencewicz J. 2015. Intensity of urban heat island and air quality in Gdańsk during 2010 heat wave. Pol. J. Environ. Stud. 23(2), 329-340.

Kossowska-Cezak U. 2014. Zmiany wieloletnie liczby termicznych dni charakterystycznych w Warszawie (1951-2010) [Multiannual variation of thermal specific days in Warsaw (1951-2010)]. Pr. Geogr. IGiGP UJ 136, 9-30. [in Polish]

Kossowska-Cezak U., Skrzypczuk J. 2011. Pogoda upalna w Warszawie (1947-2010) [Hot weather in Warsaw (1947-2010)]. Pr. Stud. Geogr. 47, 139-146. [in Polish]

Kossowska-Cezak U., Twardosz R. 2013. Niezwykle chłodne sezony letnie w Europie Środkowej i Wschodniej (1951-2010) [Exceptionally cool summers in Central and Eastern Europe (1951-2010)]. Prz. Geofiz. 1-2, 25-39. [in Polish]

Koźmiński C., Michalska B. 2000. Klimatyczna charakterystyka rejonu stacji agrometeorologicznej w Lipkach k. Starogardu Szczecińskiego. Szczecin, Wydaw. AR. [in Polish]

Koźmiński C., Michalska B. 2010. Zmienność liczby dni gorących i upalnych oraz odczucia cieplne w strefie polskiego wybrzeża Baltyku [Variability in the number of hot, very hot days and thermal perception at the Polish Baltic Coast]. Acta Agrophys. 15(2), 347-358. [in Polish]

Koźmiński C., Michalska B. 2011. Zmienność liczby dni zimnych, chłodnych, ciepłych, gorących i upalnych w Polsce w okresie kwiecień-wrzesien [Variability in the numbers of cold, cool, warm, hot, and very hot days in Poland in the April-September period]. Prz. Geogr. 83(1), 91-107. [in Polish]

Koźmiński C., Michalska B., Czarnecka M. 2012. Klimat województwa zachodniopomorskiego. Szczecin, AR. [in Polish]

Krzyżewska A. 2015. Fale upałów i ich skutki na przykładach z Europy i Ameryki Północnej, w: Klimat a społeczeństwo i gospodarka. Red. H. Lorenc, Z. Ustrnula. Warszawa, Wydaw. PTG, 161-174. [in Polish]

Matuszko D., Piotrowicz K. 2012. Wieloletnia zmienność sytuacji meteorotropowych w Krakowie [Long-term variability of meteotropic situations in Kraków]. Prz. Geogr. 84(3), 413-422.

Michalska B. 2011. Tendencje zmian temperatury powietrza w Polsce [Tendencies of air temperaturę changes in Poland]. Pr. Stud. Geogr. 47, 67-75. [in Polish]

Nidzgorska-Lencewicz J., Mąkosza A. 2013. Assessment of bioclimatic conditions within the area of Szczecin agglomeration. Meteorolog. Zeitschr. 22(5), 615-626.

Piotrowicz K. 2007a. Temperatura powietrza, w: Klimat Krakowa w XX wieku. Kraków, IGiGP UJ, 99-112. [in Polish]

Piotrowicz K. 2007b. Wieloletnie zróżnicowanie liczby nocy gorących w Krakowie, w: Wahania klimatu w różnych skalach przestrzennych i czasowych. Red. K. Piotrowicz, R. Twardosz. Kraków, Wydaw. IGiGP UJ, 279-286. [in Polish]

Starkel L., Kundzewicz Z. W. 2008. Konsekwencje zmian klimatu dla zagospodarowania przestrzennego kraju [Consequences of climate change for spatial organization of Poland]. Nauka 1, 85-101. [in Polish]

Trepińska J. 2005. Termiczne skrajności w „umiarkowanym” klimacie Polski, w: Ekstremalne zjawiska hydrologiczne i meteorologiczne. Red. E. Bogdanowicz, U. Kossowskiej-Cezak, J. Szkutnicki. Warszawa, PTG, 55-63. [in Polish]

Trepińska J., Kopycki J. 2009. Termiczne zagrożenia wywołane zmianami klimatu w różnych dziedzinach życia człowieka i gospodarki [Risks caused by the climate change to different areas of human life and economy]. Prob. Ekol. 13(4), 199-210. [in Polish]

Twardosz R., Kossowska-Cezak U. 2015. Extremely cool summers in Central and Eastern Europe (1951-2010). Nat. Hazards 75(2), 2013-2026.

Wibig J., Głowicki B. 2002. Trends of minimum and maximum temperature in Poland. Clim. Res. 20(2), 123-133.

Więcław M. 2015. Bardzo ciepłe i gorące noce w północno-zachodniej Polsce [Very warm and hot nights in north-western Poland]. J. Educ. Health Sport 5(12), 31-40. [in Polish] 
Yan Z., Jones P.D., Davies T.D., Moberg A., Bergstrom H., Camuffo D., Cocheo C., Maugeri M., Demaree G.R., Verhoeve T., Thoen E., Barriendos M., Rodriguez R., Martin-Vide J., Yang C. 2002. Trends of extreme temperatures in Europe and China based on daily observations. Clim. Change 53(1-3), 355-392.

Ziemiański M., Ośródka L. 2012. Zmiany klimatu a monitoring i prognozowanie stanu środowiska atmosferycznego. Warszawa, IMiGW. [in Polish]

\begin{abstract}
Days with air temperature (maximum or minimum) exceeding a specific threshold values constitute the grounds for analysing extreme temperature indices. Such days are the fundamental thermal characteristics of an area under analysis. Days with particularly low or high air temperature are relevant to various spheres of life, including human health and life and economy. The aim of this paper is the analysis of the variability and frequency of temperature indices occurrence in the Pyrzycko-Stargardzka Plain mesoregion in the period 1961-2015. The source material used in this study included maximum and minimum 24-hour air temperatures as recorded at agrometeorological station in Lipnik - located in the central part of the Plain. The classification created by Kossowska-Cezak (2014) was adopted to determine days with particular temperature indices. It was found that days with given temperature thresholds were recorded more frequently $(24.0 \%)$ in a cold part of a year, than those characteristic for a warm part $(8.9 \%)$. The results indicate a statistically significant negative trend in the total number of frost days, cold days, very cold days and a positive trend in the total number of days described as hot, very hot and extremely hot days. The most apparent statistically significant decrease was found for cold days (3.6 per 10 years), and increase for hot days (2.3 per 10 years). In the analysed period the most frequent were frost days (62.4) and hot days (26.7). Annualy, 15.7 nights with particular temperature indices were recorded - mostly classified as warm nights. The analysis showed a statistically significant increase (by 2.5 per 10 years) in the number of nights with particular temperature indices.
\end{abstract}

